\title{
V/F SPEED CONTROL OF SOLAR PV SYSTEM FED INDUCTION MOTOR DRIVE
}

\author{
Ch. Madhan mohan ${ }^{1}$, V.S.Vakula ${ }^{2} \&$ R.S R Krishnam Naidu ${ }^{3}$
}

Abstract- This Paper mainly focusing on the utilization of renewable energy i.e., solar energy to drive the induction motor. Since to reduce burden on conventional energy sources there is need to move towards solar energy to supply power to electrical loads. Solar power generation is a clean and pollution free power generation and it is inexhaustible power generation too. In this paper, simulations of solar photovoltaic system fed induction motor is presented and analyzed briefly. In addition to this, controlling of solar photovoltaic system with fast digital controller i.e. FPGA has also been presented. An MPPT charge controller is used in solar energy harvesting applications to extracts the maximum power from an ambient solar energy source even under variations in light intensity and temperature. Initial stage FPGA controlled charge controller provides constant DC power at its output terminals and it is converted into AC by using FPGA controlled 3- level diode clamped inverter. In this paper open circuit voltage mode FPGA controlled MPPT charge controller is designed to get constant DC power from solar PV module. This DC power is act as a source to FPGA controlled 3-Level inverter; and converts into AC power by this inverter. Sinusoidal Pulse Width Modulation (SPWM) is implemented in Xilinx system generator environment and MATLAB to control the inverter. This inverter output is used to feed the induction motor. THDs of voltages and currents of 3-level inverter and induction motor are also observed

Keywords - Solar PV system, Solar PV cells/modules, MPPT Technique, System model, DC-DC Boost converter, FPGA control algorithm.

\section{INTRODUCTION}

From few decades onwards the power demand grows very high and the generation is not able to reach proportionally to meet the demand due to the lack of conventional energy sources. There by we are looking for alternative sources to generate electrical energy such as renewable energy sources like solar, wind, geothermal, etc...Because the renewable sources having several advantageous like inexhaustible in nature, free of cost, pollution free, less maintenance and these generating stations can be installed at load center only. In this paper we are mainly focusing on the solar energy system and convert into electrical energy by using solar PV system.

Solar generation is not same throughout the day, it's depends on the time and weather conditions because the Sun radiation is varies time to time. Solar PV System consist number of solar panels which will directly converts solar energy into electrical energy. The output of PV System is very sensitive to shading conditions i.e. in cloudy times the output falls dramatically. Therefore the generated energy form the Solar PV System varies significantly.

Solar System Consist of photovoltaic panels which will receive the solar energy and converts into DC current, this generated energy is then converted into three-phase alternating current (AC) by means of an Inverter. To track the maximum solar radiation a Tracking mechanism is used. A storage system (Battery) is used to store the part of the generated energy in the form of DC. A single unit of solar PV System can generate the power to individual electrical appliances like a single phase motor used in domestics. The power generated by the PV System can be either stored or can used directly by connecting to the grid system.

\section{PROPOSED MODEL}

You can then continue to the low frequency components of the same upper left corner of the 2nd, 3rd inferior wavelet transform. A photovoltaic system is a collection of solar panels or modules or cells. A single or individual solar provides a low voltage (typically $0.5 \mathrm{~V}-0.7 \mathrm{~V}$ ); therefore a series of modules are connected in series to meet a desired voltage levels and the modules are connected in parallel to produce more current.. An inverter is connected to PV arrays to convert the produced DC power by the modules into (AC) alternating current which is useful to many electrical appliances. Solar panels are typically measured under STC (standard test conditions) or PTC (PVUSA test conditions), in watts. Typical panel ratings range from less than 100 watts to over 400 watts. The array rating consists of a summation of the panel ratings, in watts, kilowatts, or megawatts.

\footnotetext{
${ }^{1}$ Department of Electrical and Electronics Engineering, PYDAH college of engineering, Kakinada, india

${ }^{2}$ Department of Electrical and Electronics Engineering, JNTUK-University College of Engineering, Vizianagaram, India.

${ }^{3}$ Department of Electrical and Electronics Engineering, GITAM University, Visakhapatnam, India
} 


\subsection{Solar Cell Model:}

Model of the solar cell consists of current source, diode, series resister, parallel resister and load resister which is shown in the below fig.1.

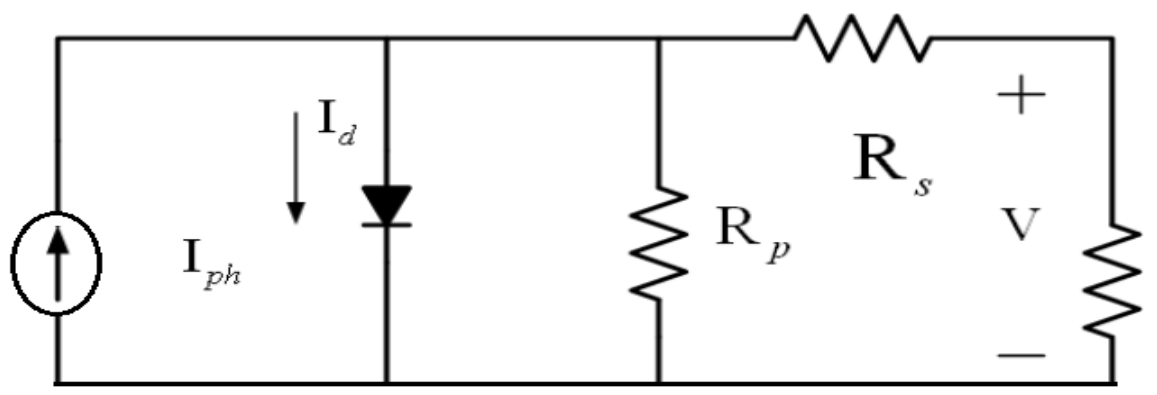

Figure 1. practicle model of solar cell

Equations :

$I=I_{\text {ph }}-I_{d}\left[\exp \left(q\left(V+I R_{g}\right) / K T_{c} A-1\right)\right]-\left(V+I R_{g}\right) / R_{p}$

I ph=Short-circuit current due to sunlight;

$\mathrm{Id}=$ Current shunted through the diode;

$\mathrm{R}=$ Load resistance;

$\mathrm{I}=$ Current through the load;

$\mathrm{V}=$ Voltage on the load;

$\mathrm{Rs}=$ series resistance;

$\mathrm{R} p=$ Shunt resistance;

$\mathrm{q}=$ Electron charge $\left(1.6 \times 10^{-10} \mathrm{C}\right)$;

$\mathrm{K}=$ Boltzmann's constant;

$I_{p h}=\left[I_{g c}+\alpha\left(T_{g}-T_{r g f}\right)\right] . G$

Where $\quad \alpha=0.0012 \times I_{s e}$

\subsection{MPPT charge converter:}

Solar inverters use maximum power point tracking (MPPT) to get the maximum possible power from the PV array. Solar cells have a complex relationship between solar irradiation, temperature and total resistance that produces a non-linear output efficiency known as the I-V curve. It is the purpose of the MPPT system to sample the output of the cells and determine a resistance (load) to obtain maximum power for any given environmental conditions. Essentially, this defines the current that the inverter should draw from the PV in order to get the maximum possible power (since power equals voltage times current). The fill factor, more commonly known by its abbreviation FF, is a parameter which, in conjunction with the open circuit voltage and short circuit current of the panel, determines the maximum power from a solar cell. Fill factor is defined as the ratio of the maximum power from the solar cell to the product of Voc and I sc. There are three main types of MPPT algorithms: perturb-and-observe, incremental conductance and constant voltage. The first two methods are often referred to as hill climbing methods; they rely on the curve of power plotted against voltage rising to the left of the maximum power point, and falling on the right. P\&O method MPPT charge controller is shown in the figure .2.

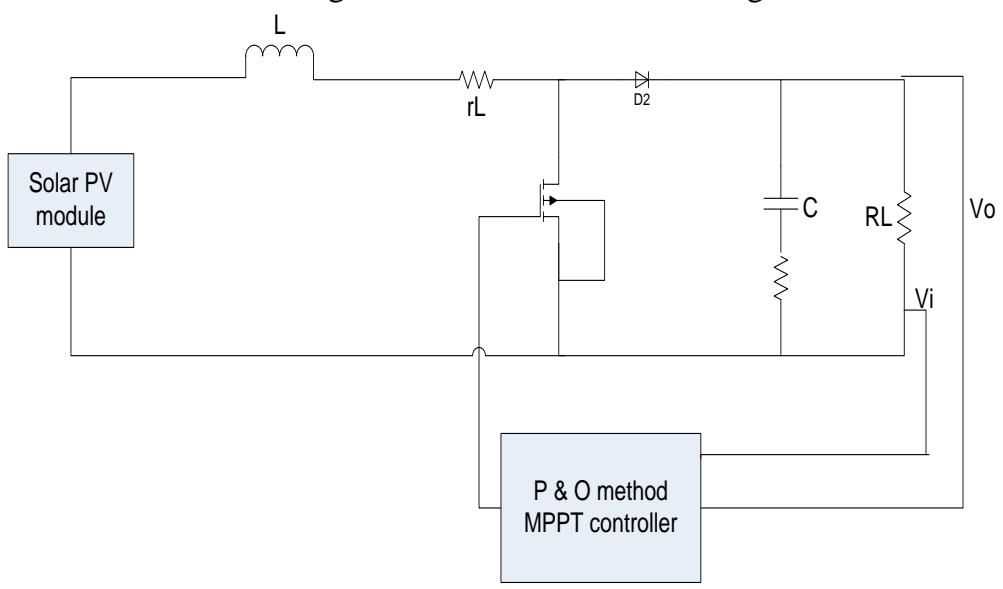

Figure 2. P\&O method MPPT charge controller 


\subsection{DC-DC Boost Converter:}

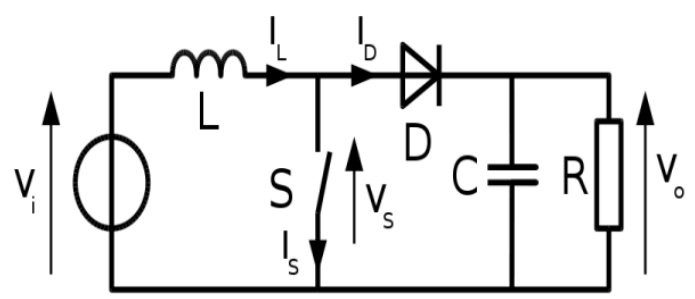

Figure 3. DC-DC Boost converter

The Boost converter is a popular power electronic converter, sometimes called a step-up power stage because output of this converter is always greater than the input. The input current for a boost power stage is continuous, or non-pulsating, because the output diode conducts only during a portion of the switching cycle. The output capacitor supplies the entire load current for the rest of the switching cycle. The DC-DC Boost converter operation depends on two ways either in charging mode or discharging mode, these are the two separate modes which depends on ON and OFF control of the switch respectively. DC-DC step up converter consists of inductor at source side, diode and capacitor at load side as main elements in the circuit. DC-DC Boost converter is shown in the figure. 3 and waveform of DC Boost converter is shown in the figure. 4.

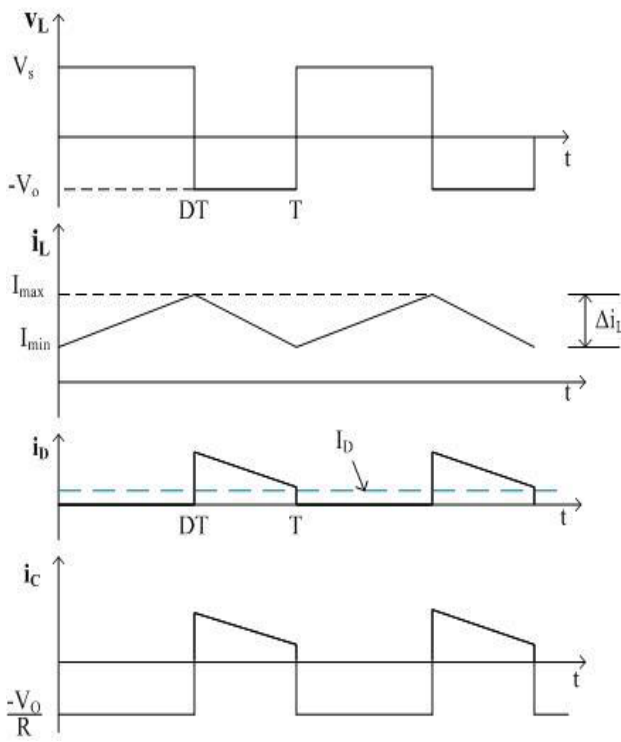

Figure 4. Waveform of D.C-D.C boost converter.

The relation between output voltage and source voltage is given as:

$V_{0}=\frac{V_{S}}{(1-D)}$

The DC-DC Boost converter used in Solar Electrical system is shown in figure.5.

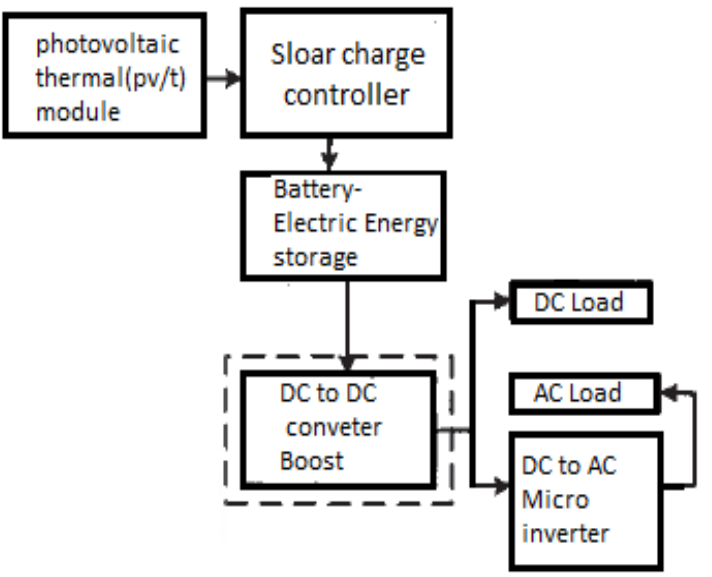

Figure 5. DC-DC Boost converter in Solar Electric System 


\section{MULTILEVEL INVERTER}

The demand of high power equipments in the range of Mega watt level by the industry has been increasing day by day, and these drives having the difficulty when interface with medium voltage grids $(2.3 \mathrm{KV}$ to $6.9 \mathrm{KV})$. The family of multilevel inverters will avoid this difficulty with medium voltage levels. Multilevel inverters uses multilevel pulse width modulation (PWM) technique so that large motors can be controlled by high-power adjustable frequency drives and can reduce the harmonic content and we can utilize the semiconductor devices in high power range. Therefore these multilevel inverters allow capability of high power handling. The components which are used in multilevel inverter are diodes, capacitors, and voltage sources. The switching losses can be minimized for a more efficient multilevel inverter by adjusting the displacement phase angle in multilevel PWM.

The advantage of this multilevel inverter at high power level is it needs not any additional coupling transformer and gives high quality output waveform. It has self voltage-balancing ability.

Different topologies have been proposed for multilevel inverters:

(1) Diode-clamped (neutral-clamped)

(2) Capacitor- clamped (flying capacitors) and

(3) Cascaded multi cell with separate dc sources

The most popular structure proposed as a transformer less voltage source inverter is the diode clamped converter.

The Control Strategies Adopted For MLI are:

(1) Multi level sinusoidal pulse width modulation (PWM)

(2) Multilevel selective harmonic elimination, and

(3) space-vector modulation (SVM).

\section{SPEED CONTROL OF AN INDUCTION MOTOR}

Induction motors are the most widely used electrical motors due to their reliability, low cost and robustness. However, induction motors do not inherently have the capability of variable speed operation. Due to this reason, earlier dc motors were applied in most of the electrical drives. But the recent developments in speed control methods of the induction motor have led to their large scale use in almost all electrical drives.

\subsection{Speed Control Techniques:}

The ideal requirement of any speed control technique is the torque produced by the machine is to maintain constant irrespective of variable speed that is constant torque variable power drive.

We have mainly two types of speed control techniques

1) Slip control technique

2) Synchronous speed control technique.

In all Slip control techniques (Voltage control, Rotor resistance and Rotor emf injection techniques) we can achieve constant torque variable power drive behavior. Here above and below rated speeds are obtained only with rotor emf injection technique. In rotor resistance and voltage control techniques only we can achieve below rated speeds.

In Synchronous speed control techniques (Frequency control, cascading of 2induction machines, pole changing technique) if below rated frequency is applied by keeping the voltage constant to maintain the torque constant, no-load and full load power factors are reduced therefore pure frequency control is not recommended, instead of this we prefer v/f control is employed for satisfactory operation of induction motor during speed control.

During v/f control technique, in order to get constant torque behavior, two conditions should be satisfied

1) V/f should be constant (i.e. air gap flux should Maintained constant)

2) The slip speed should be maintained constant

If above conditions are satisfied, then three phase induction machine acts as constant torque-variable power drive in the range of below rated speeds. If we need above rated speed then pure frequency control is possible , v/f control is not possible because voltage cannot be increased to above rated voltage, if so more stress on the insulation of windings and may get damage.

As v/f ratio cannot be maintain constant, with pure frequency control technique, the torque produced by induction machine cannot be maintain constant. That's why in above rated speed the induction machine acts as constant power-variable torque drive. Torque -speed curves have been shown in figure 6 and figure 7. 


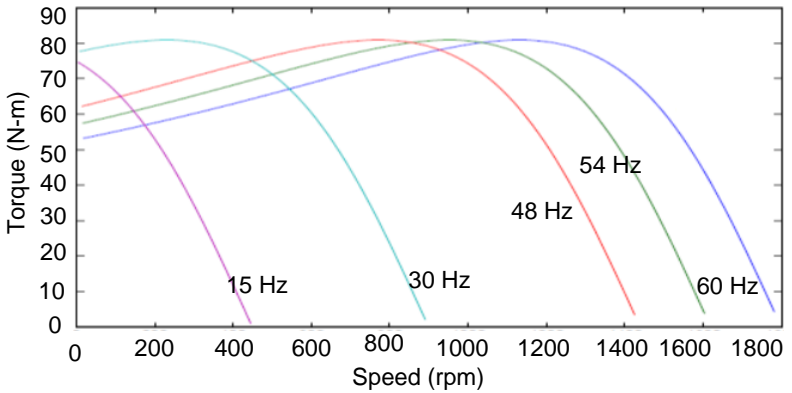

Figure 6. Torque-speed curves with V/f held constant

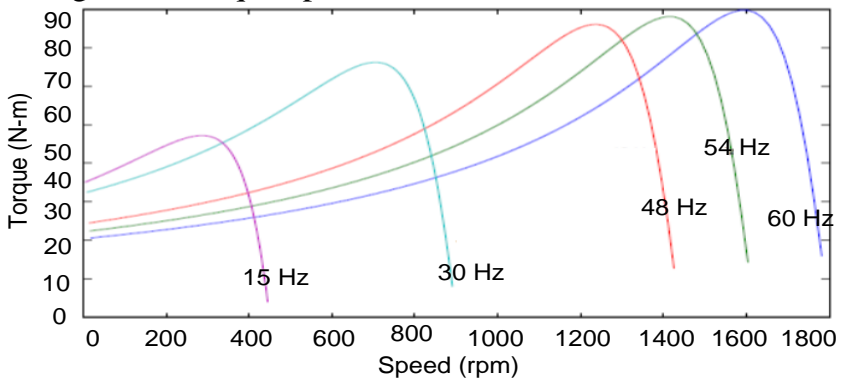

Figure 7. Torque-speed curves with V/f constant

\subsection{Closed loop V/F Speed Control of IM:}

The basis of constant V/f speed control of induction motor is to apply a variable magnitude and variable frequency voltage to the motor. Both the voltage source inverter and current source inverters are used in adjustable speed ac drives. The following block diagram shows the closed loop V/f control using a VSI. A speed sensor or a shaft position encoder is used to obtain the actual speed of the motor. It is then compared to a reference speed. The difference between the two generates an error and the error so obtained is processed in a Proportional controller and its output sets the inverter frequency. The synchronous speed, obtained by adding actual speed $\omega \mathrm{f}$ and the slip speed $\omega s \mathrm{sl}$, determines the inverter frequency. The reference signal for the closed-loop control of the machine terminal voltage Vs is generated from frequency. Block diagram for closed loop V/f control on a 3-ph IM is shown in the figure.8.

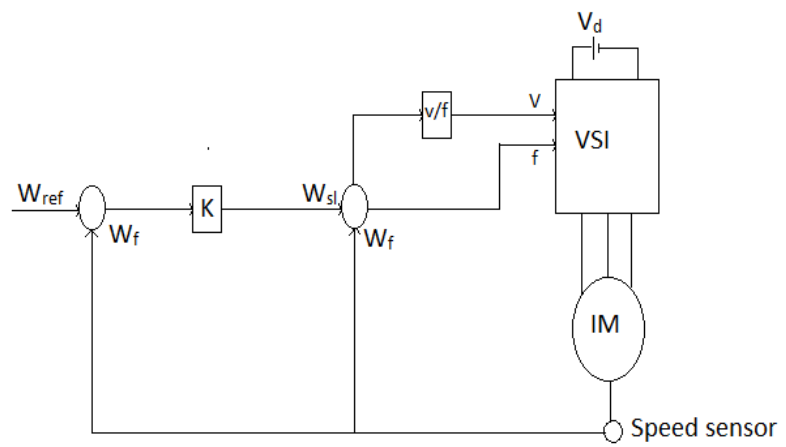

Figure 8. Block diagram for closed loop V/f control on a 3-ph IM

\section{RESULTS AND DISCUSSION}

Figure 9 shows the temperature $(\mathrm{k})$ variation, maximum temperature obtained arround $307 \mathrm{k}$ and minimum temperature obtained is $292 \mathrm{k}$. Figure 10 shows the system ambient irradiation in $\mathrm{w} / \mathrm{m}^{2}$, maximum irradiance occurred at $1030 \mathrm{w} / \mathrm{m}^{2}$. Figure 11. Shows the solar pannel constant output current of 4.5 amps. . Figure 12. Shows the solar module output voltage of $25 \mathrm{~V}$ dc. Figure 13. Shows the Charge controller voltage, setteled at $350 \mathrm{~V}$. Figure 14. And Figure 15.shows the phase and Line to line voltage of multi level inverter respectively. Figure 16. Shows the transiant and steady state mode of induction machine curret. Figure 17. Shows the speed of induction motor with $1500 \mathrm{rpm}$ set speed 


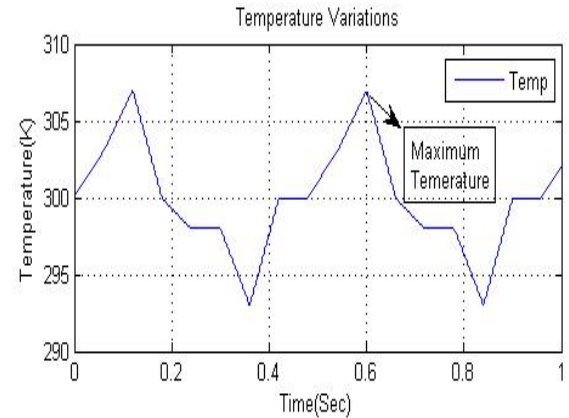

Figure 9 temperature $(\mathrm{k})$ variation

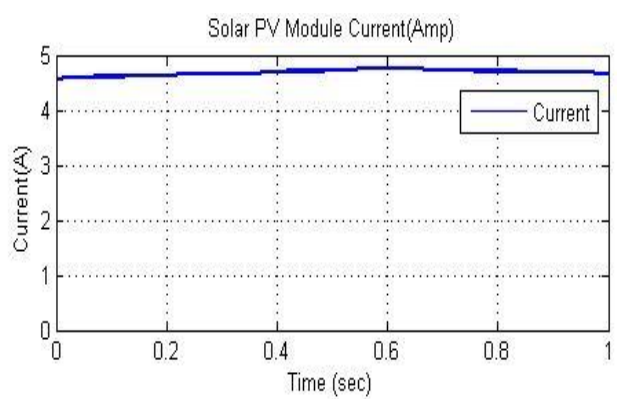

Figure 11. Solar pannel constant output current

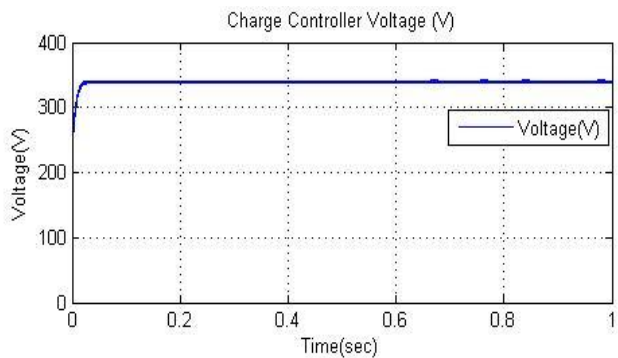

Figure 13. Charge controller voltage
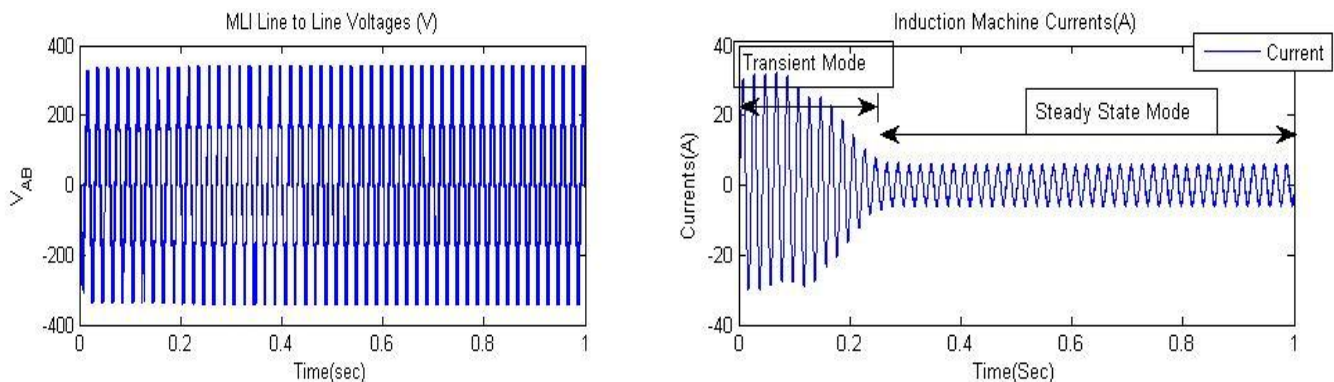

Figure 15. Line to line voltage of MLI Figure 16. Transiant and steady state mode of induction machine cuttet

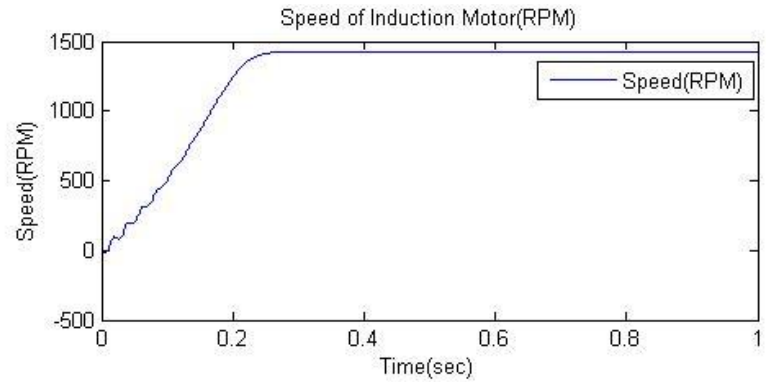

Figure 17. speed of induction motor with $1500 \mathrm{rpm}$ set speed 


\section{CONCLUSION:}

Results have been taken to analyze the system based on the Simulations model of proposed system in MATLAB Simulink platform. Firstly, design of system started with the design of induction motor by considering the water pump as a load, after that design of solar PV array is completed to meet the demand of induction motor fed load. Designed solar PV array consists of solar PV models with module based MPPT charge controllers and these boost converter based MPPT charge controllers are controlling with the help of P\&O method MPPT to extract maximum power from the modules. And all the solar PV modeled based MPPT charge controllers are connected in parallel to meet the current demand of the load. After completion of design, Simulink modeling has done. Based on the simulation results which have been presented in previous section it is concluded that proposed system is proper, and is running successfully the water pump load in Xilinx interfaced MATLAB Simulink platform.

\section{REFERENCES}

[1] T. Muthamizhan and R. Ramesh, "Design and Simulation of PV driven three phase Induction motor", International Review on Modelling and Simulations, vol. 6, no. 2, pp. 412-418, April. 2013.

[2] R. Arivazhagan and S. L. Prakash, "Analysis of current-fed full bridge converter with modified auxiliary circuit", Proceedings of the international Conference on in Recent Advancements in Electrical, Electronics and Control Engineering, pp. 357-362, 2011.

[3] G.S. Buja and M.P. Kazmierkowski, 'Direct torque control of PWM inverter-fed AC motors - A survey", IEEE Transactions on Industrial Electronics, vol. 51, no. 4, pp. 744-757, 2004.

[4] R.Y. Chen, T.J. Liang, J.F.Chen, R.L. Lin and K.C. Tseng, 'Study and implementation of a current-fed full-bridge boost DC-DC converter with zerocurrent switching for high-voltage applications', IEEE Transactions on Industry Applications, vol. 44, no. 4, pp. 1218-1226, 2008.

[5] A. Choudhury and K. Chatterjee, 'Speed sensor less direct torque controlled induction motor drive with constant switching frequency operation', Proceedings of the international conference on Energytech,2011, pp. 1-6.

[6] Hahn, - Technical maturity and reliability of photovoltaic pump systems,॥ in Proc. 13th Eur. Photovoltaic Solar Energy Conf., Nice, France, pp. 17831786.

[7] M. A. Vitorino and M. B. R. Correa, -High performance photovoltaic pumping system using induction motor,\| in Proc. Brazilian Power Electron. Conf., 2009, pp. 797-804.

[8] D. Tschanz, H. Lovatt, A. Vezzini, and V. Perrenoud, -A multi-functional converter for a reduced cost, solar powered, water pump,\| in Proc. IEEE ISIE, 2010, pp. 568-572.

[9] M. A. Vitorino, M. B. R. Correa, C. B. Jacobina, and A. M. N. Lima, -An effective induction motor control for photovoltaic pumping,ll IEEE Trans. Ind. Electron., vol. 58, no. 4, pp. 1162-1170, Apr. 2011.

[10] S. R. Bowes and A. Midoun, - Suboptimal switching strategies for microprocessor controlled PWM inverter drives,\| Proc. Inst. Elect. Eng.-Elect. Power Appl., vol. 132, no. 3, pp. 133-148, May 1985.

[11] M. Cacciato, A. Consoli, and V. Crisafulli, - A high voltage gain $\mathrm{dc} / \mathrm{dc}$ converter for energy harvesting in single module photo voltaic applications, in Proc. IEEE ISIE, 2010, pp. 550-555.

[12] W. Li, L. Fan, Y. Zhao, X. He, D. Xu, and B. Wu, - High step-up and high efficiency fuel cell power generation system with active clamp flybackforward converter,\| IEEE Trans. Ind. Electron., vol. 59, no. 1, pp. 599- 610, Jan. 2012.

[13] P. M. Barbosa and I. Barbi, -A new current-fed, isolated PWM dc-dc converter,\| IEEE Trans. Power Electron., vol. 11, no. 3, pp. 431-438, May 1996.

[14] B. Liu, C. Liang, and S. Duan, —Design considerations and topology selection for dc-module-based building integrated photovoltaic system,l in Proc. 3rd IEEE Conf. ICIEA, Jun. 3-5, 2008, pp. 1066-1070.

[15] D. Li, B. Liu, B. Yuan, X. Yang, J. Duan, and J. Zhai, -A high step-up current fed multi-resonant converter with output voltage doubler, R. Faranda and S. Leva, -Energy comparison of MPPT techniques for PV systems,\| WSEAS Trans. Power Syst., vol. 3, no. 6, pp. 446-455, Jun. 2008

[16] M. Liserre, F. Blaabjerg, and S. Hansen, -Design and Control of an LCL-Filter-Based Three-Phase Active Rectifier,ll IEEE Transactions on Industry Applications, vol. 41, no. 5, pp. 1281- 1291, Sep. 2005.

[17] V. Blasko and V. Kaura, -A Novel Control to Actively Damp Resonance in Input LC Filter of a Three-Phase Voltage Source Converter,\| IEEE Transactions on Industry Applications, vol. 33, no. 2, pp. 542-550, 1997.

[18] M. Rajendar Reddy, T. Brahmananda Reddy, 1. Amarnath and D. Subba Rayudu — Space Vector Based Novel and Simple Unified Pulsewidth Algorithm for Induction Motor Drives" IJIEC Volume 2, No.1, pp. 9- 32,2010.

[19] V. T. Somasekhar, B. Venugopal Reddy" A New Four-level Dual Inverter fed Open-end Winding Induction Motor Drive" IEEE PEDS 2011,PP.167170 Singapore, 5 - 8 Dec-2011.

[20] Koutroulis E., Dollas A. and Kazantzakis K., - High-frequency pulse width modulation implementation using FPGA and CPLD ICsll, Journal of Systems Architecture, Vol.52 (2006): pp. 332-344

[21] Rahim N.A. and Islam Z., -Field Programmable Gate Array-Based Pulse-Width Modulation for Single Phase Active Power Filterll; American Journal of Applied Sciences, Vol.6 (2009): pp. 1742-1747

[22] Dancy A.P., Amirtharajah R. and Chandrakasan A.P., - High-Efficiency Multiple-Output DC-DC Conversion for Low-Voltage Systemsll, IEEE Trans. on Very Large Scale Integration (VLSI) Systems, Vol. 8, No. 3, June 2000: pp.252-2

[23] Langridge D, Lawrence W, Wichert B. High-efficiency solar water pumping systems using a BDC motor. In: 12th European photovoltaic solar energy conference, Netherlands; 1994. p. 227-30.

[24] J. Shao, D. Nolan, M. Teissier, D. Swanson, -A Novel Microcontroller- Based Sensorless Brushless DC (BLDC) Motor Drive for Automotive Fuel Pumpsll, IEEE Trans. on Ind. Appl., vol. 39, no. 6, Nov./Dec. 2003.

[25] J. Shao, -An Improved Microcontroller-Based Sensor less Brushless DC (BLDC) Motor Drive for Automotive Applicationsll, IEEE Trans. On Ind. Appl., vol. 42, no. 5, Sept./Oct. 2006, pp. 1216-1221. 253 